\title{
Godt nok dokumentert?
}

Leger foreslår og iverksetter en rekke tiltak, både som klinikere og samfunnsmedisinere. Ofte er det betydelig usikkerhet knyttet til konsekvensene og legene er gjerne uenige seg imellom - noen sverger til behandling A, mens andre er overbevist om at B er best. En av grunnene til dette kan være at behandlingene som tilbys, har liten eller moderat virkning - eller kanskje ingen. Noen pasienter blir bedre, andre blir det ikke. Da er det naturlig at enkelte leger har god klinisk erfaring med én behandlingsform og andre ikke. Gullstandardmetoden for å avklare virkningene av et tiltak er å gjennomføre et randomisert, kontrollert forsøk. Ved å trekke lodd om hvem som får og hvem som ikke får behandlingen, lager vi to sammenliknbare grupper og kan finne ut hvor effektivt tiltaket er.

Noen ganger er det ingen tvil om at det vi gjør er virkningsfullt. Alle som har gitt morfin til en person med sterke smerter, er enige om at dette har en dramatisk, rask effekt. Motgift ved heroinoverdose likeså. Andre tiltak har kanskje ikke samme umiddelbare effekt, men virkningene er like dramatiske. Penicillin ved alvorlig meningokokksykdom og insulin ved diabetes type 1 er eksempler på det. Samtidig er det lett å la seg lure. Gir du penicillin til pasienter med mellomørebetennelse, blir de fleste friske i løpet av en dag eller to. Gjennom slike observasjoner blir man forledet til å tro at penicillinbehandling er helbredende - hvis man ikke tar med i betraktningen at de fleste ville blitt friske også uten (1). Det meste går heldigvis over av seg selv, også med uhensiktsmessig behandling. Tvilsomme teorier og «klinisk erfaring» bidro formodentlig til at f.eks. årelating ble regnet som god behandling for det meste, også diarésykdommer, i hundrevis av år. Kravene som stilles til dokumentasjon har endret seg mye de siste tiårene. Nå skal det være kunnskapsbasert - «evidence-based». Og godt er det.

I dette nummer av Tidsskriftet rapporterer Guldbakke og medarbeidere om sin erfaring med utprøvning av en ny medikamentell behandlingsmetode - propranolol - for infantilt hemangiom (2). De beskriver en pasient med påfallende rask bedring etter behandlingsstart: Svulsten gikk tilbake langt raskere enn man ellers ville ha forventet. I utgangspunktet er det all grunn til å være skeptisk til denne type «dokumentasjon». Serien av anekdoter om fantastiske resultater - som senere viste seg ikke å holde vann - er lang. Den aktuelle pasienthistorien fra St. Olavs hospital illustrerer en viktig og vanskelig diskusjon: Hva skal til av dokumentasjon for å kunne anta at en behandling sannsynligvis vil gagne pasienten? Infantile hemangiomer går som regel tilbake av seg selv i løpet av barneårene, men svulstens lokalisering kan gjøre at det likevel er påkrevd med tiltak. Det mest dramatiske eksemplet er hemangiom i luftveiene, som kan føre til kvelning.

Bruken av propranolol i behandlingen av infantilt hemangiom kan betraktes som eksperimentell. Den tilsynelatende virkningen ble oppdaget ved en tilfeldighet for et par år siden, og bare noen titalls tilfeller er siden den gang beskrevet i faglitteraturen. Vi aner lite om hva som kan være mekanismen bak en eventuell effekt. Dessuten innebærer behandling med propranolol og andre betablokkere risiko for bivirkninger, så det er all grunn til å være forsiktig.

Betyr dette at det drives uansvarlig, eksperimentell pasientbehandling ved hudavdelingen ved St. Olavs hospital? Svaret på det avhenger av hvordan man vurderer kvaliteten på den foreliggende dokumentasjonen for bruk av propranolol ved infantilt hemangion. De franske legene som først observerte den tilsynelatende effekten av proporanololbehandling hos et barn med både hjertesykdom og hemangiom, fulgte opp med å gi behandlingen til en serie på 11 pasienter (3). De fant klare tegn til bedring i løpet av få dager hos alle sammen. Etter dette har engelske hudleger rapportert resultatene fra en serie på 30 pasienter - igjen klar bedring hos alle sammen langt raskere enn man vanligvis ville forvente (4).

Behandlingsresultater fra slike pasientserier blir gjerne møtt med skepsis. Og med god grunn - observasjoner fra et dusin pasienter forteller lite om hvordan det ville gått med dem dersom de ikke hadde fått behandlingen. Vi mangler «kontrollgruppe». Dessuten: Var de som fikk behandlingen, representative for hele pasientgruppen, eller gjorde legene et selektivt utvalg? Får vi vite hvordan det gikk med alle som fikk behandlingen, eller kan legene ha bedrevet selektiv rapportering? Hvordan ble behandlingsresultatet målt - ved at de entusiastiske legene som sto bak studien gjorde sine egne subjektive vurderinger? Mulige feilkilder er mange.

Det som er spesielt med pasientseriene der man har forsøkt propranolol ved infantilt hemangiom, er at alle så raskt ble klart bedre - uten unntak. Det er vanskelig å tenke seg at feilkilder kan forklare et så overbevisende behandlingsresultat. Er den foreliggende dokumentasjonen dermed god nok til at propranolol kan anbefales brukt i vanlig klinisk praksis? Her finnes ingen fasitsvar, men for å kunne veie fordelene og ulempene ved å underlegge barnet et slikt behandlingsregime er det ønskelig med så robust kunnskap som mulig. Derfor er det godt nytt at flere randomiserte forsøk allerede er i gang, forsøk der barn med infantilt hemangiom blir tilfeldig fordelt til å få behandling med betablokker eller med placebo (5).

Barn med livstruende eller funksjonsnedsettende hemangiomer er ikke med i de pågående studiene. Og det skulle bare mangle! Basert på den kunnskap vi besitter i dag, er det rimelig å anta at fordelene ved å forsøke propranololbehandling veier langt tyngre enn ulempene for disse barna. Pasienten som beskrives i artikkelen fra St. Olavs hospital er et godt eksempel på det.

\section{Atle Fretheim}

atle.fretheim@kunnskapssenteret.no

Atle Fretheim (f. 1968) er forskningsleder ved Nasjonalt kunnskapssenter for helsetjenesten og førsteamanuensis ved Insitutt for helse og samfunn, Universitetet i Oslo. Han har arbeidet med forskning om effekter av tiltak i helsetjenesten i ti år.

\footnotetext{
Litteratur

1. Sanders S, Glasziou PP. Del Mar C et al. Antibiotics for acute otitis media in children. Cochrane Database Syst Rev 2004, nr. 1: CD000219. DOI: 10.1002/ 14651858.CD000219.pub2.

2. Guldbakke KK, Rødam 0-M, Huldt-Nystrøm T et al. Behandling av infantilt hemangiom med propanolol. Tidsskr Nor Legeforen 2010; 130: 1822-4.

3. Léauté-Labrèze C, Dumas de la Roque E, Hubiche T et al. Propranolol for severe hemangiomas of infancy. N Engl J Med 2008; 358: 2649-51.

4. Manunza, F, Syed S, Laguda B et al. Propranolol for complicated infantile haemangiomas: a case series of 30 infants. Br J Dermatol 2010; 162: 452-68.

5. ClinicalTrials.gov [Database]. www.clinicaltrials.gov/ct2/ results?term=infantile+hemangiomas (25.6.2010).
} 